\title{
Management of Diabetes mellitus and its complications by Lodhra: A review
}

\author{
Review Article
}

\section{Varun Kumar Singh ${ }^{1^{*}}$, Reddy KRC $^{2}$}

1. Ph. D Scholar (DST-INSPIRE Fellow), 2. Professor, Department of Rasa Shastra, Faculty of Ayurveda, Institute of Medical Sciences, Banaras Hindu University, Varanasi

\begin{abstract}
In Ayurveda, Lodhra is a used for many ailments either as single ingredient or part of formulation. It has been used for thousands of years to manage Kapha-Pitta based disease and specially to improve women's health in Ayurvedic science. Observations: Among these ailment, it was also indicated for Prameha (Diabetes) in many authoritative books of Ayurveda (First schedule of The Drugs and Cosmetics Act 1940). Contemporary science also proofs its antidiabetic property by recent researches. The clinical course and prognosis of health and life of diabetic patient are now largely determined by so called complications of diabetes. Other properties of Lodhra viz. healing property, antioxidant property, anti-microbial property, anti-ulcer property etc. may be utilized against diabetic complications. Aim and Objective: Author present here comprehensive review of Lodhra for its antidiabetic property and investigate its pharmacodynamics that may help to keep away diabetic complications and other problems of daily life.
\end{abstract}

Key words: Lodhra, Antidiabetic, Prameha, Ayurveda, Diabetic complications

\section{Introduction}

Indian Subcontinent was served by Ayurveda since 1000 B.C. with objectives to achieve physical, mental, social and spiritual health by its treatment and life style wisdom (1). In $21^{\text {st }}$ century, when world mindset is being attracted towards nature based medical service and start looking towards traditional system of medication, scholars are trending towards plant based researches. Contemporary science flourish data as a large evidence that has been available to show the huge potential of medicinal plants used in various traditional systems and to put a current scientific proof for ancient wisdom (2). In sanskrit "Lodhra" is meant for 'Propitious'\& 'Tilaka', as the bark of the tree was used in making the Tilaka mark on the forehead so the plant was named as Lodhra (3). In Europe, it was formerly known as a Cinchona bark and had been known at various time as "Encorce de lautour", "China nova" \& "China paraquatan"(4). In Many of the traditional systems, one common vernacular name has been used for plants of different species leading to adulteration or accidental misuse of the plant (5). Symplocos racemosa Roxb., which is 6 to 8.5 metres tall, found abundantly in the plains and lower hills throughout India. Lodhra bark has astringent, styptic, anti-inflammatory, and antimicrobial Properties. No adverse effect of Lodhra powder is reported when taken in recommended doses. It is also found safe for the baby if a nursing mother is

\footnotetext{
*Corresponding Author:

Varun Kumar Singh

Ph. D Scholar (DST-INSPIRE Fellow)

Faculty of Ayurveda,

Institute of Medical Sciences,

Banaras Hindu University, Varanasi

Phone number: +91-8004215154

E-mail: varun.imsbhu@gmail.com
}

taking this medication. However, Lodhra powder should not be used for along duration during pregnancy (6).

Diabetes is fast spreading metabolic vascular syndrome of multiple aetiologies characterise by chronic hypoglycaemia with distribution of carbohydrates, fats, protein metabolism (7). In current era, the complications related with diabetes are more dangerous than diabetes itself, so treatment approach are modifying to treat diabetes along with prevention of its complications. WHO (World Health Organization) have reported many complications that may be kept away by using the preventive pharmacology of Lodhra viz. antioxidant property, anti-microbial property, antiulcer property etc.

\section{Phytoconstituents of Lodhra}

Mostly the bark of the Lodhra (Symplocos racemosa) was used in Ayurvedic formulation that contains Colloturine, Harman (Loturine) and Loturidine and Proanthocyanidin-3-monoglucofuranosides of 7-Omethyl-and 4'-Omethyl- leucopelargonidin. Betulinic, oleanolic, acetyl oleanolic and ellagic acids are also reported from the plant. Glycosides, isolated from the ethanolic extract of the stembark, are highly astringent and are reported to be responsible for the medicinal properties of the bark (8). Other chemical constituents are also reported in different researches (Table-1).

\section{Properties and Indications of Lodhra in Ayurveda \\ Lodhra is having Laghu, Ruksha guna, Kashaya} rasa, Katu veerya and Sheeta vipaka according to Ayurvedic science. It is Kapha-Pitta shamak due to its Kashaya and Sheeta property that was utilized in treatment of Kaphaj prameha. It has been used as netra hitkara \& rakta dosha nashaka (17). Due to its pitta and kapha dosha pacifying activities i.e., it mitigates vitiated forces (doshas) of body. It is also helpful in cleaning of wound, holds bleeding \& initiates fast 
healing process. It was used as single ingredient as well as part of the formulation. In case of Prameha, Lodhra was used in Pramehaghna yoga (Antidiabetic formulations) and its other properties may be utilized against complications arises either due to diabetes mellitus of during the disease (Table-2).

\section{Table.1. Phytoconstituents of Symplocos species}

\begin{tabular}{|c|c|c|c|}
\hline $\begin{array}{l}\text { Sr. } \\
\text { No. }\end{array}$ & Class & Constituents & References \\
\hline 1 & $\begin{array}{l}\text { Flavanol } \\
\text { glucosides }\end{array}$ & $\begin{array}{l}\text { Symplocoside, } \\
\text { Symposide, } \\
\text { Leucopelargonid } \\
\text { in 3-Glucoside, } \\
\text { Ellagic Acid, } \\
\text { Rhamnetin 3- } \\
\text { Galactoside. } \\
\text { Triterpenoids: } \\
\text { 19 A- } \\
\text { Hydroxyarjunoli } \\
\text { c Acid-3, 28-O- } \\
\text { Bis-B- A- } \\
\text { Glucopyranosid } \\
\text { es, 19 By } \\
\text { Hydroxyasiatic } \\
\text { Acid-3, Betulin, } \\
\text { Oleanolic Acid, } \\
\text { B- Sitosterol \& } \\
\text { A-Amyrin }\end{array}$ & 9,10 \\
\hline 2 & Alkaloids & $\begin{array}{l}\text { Loturine, } \\
\text { Isoloturine } \quad \& \\
\text { Harmane }\end{array}$ & 11 \\
\hline 3 & $\begin{array}{l}\text { Phenolic } \\
\text { Glycosides }\end{array}$ & $\begin{array}{l}\text { Benzoylsalirepo } \\
\text { side ,Symconosi } \\
\text { de A \& } \\
\text { Symconoside } \\
\text { B } \\
\text { Symplocuronic } \\
\text { Acid \& } \\
\text { Sympocernoside } \\
\text { b-amyrin, b- } \\
\text { sitosterol }\end{array}$ & $12,13,14$ \\
\hline 4 & $\begin{array}{l}\text { Ethyl } \\
\text { Substituted } \\
\text { Glycosides }\end{array}$ & $\begin{array}{l}\text { Ketochaulmoogr } \\
\text { ic Acid, } \\
\text { Nonaeicosanol, } \\
\text { Triacontyl } \\
\text { Palmitate, } \\
\text { Methyl } \\
\text { Triacontanoate } \\
\text { and one new 1- } \\
\text { Ethylbrachiose- } \\
\text { 3'-Acetate }\end{array}$ & 15 \\
\hline 5 & Triterpenoid & $\begin{array}{l}\text { betulin and } \\
\text { oleanolic acid }\end{array}$ & 16 \\
\hline
\end{tabular}

Table.2. Lodhra in (Antidiabetic formulations)

Pramehaghna yoga

\begin{tabular}{|c|c|c|c|}
\hline $\begin{array}{l}\text { S. } \\
\text { N } \\
\text { o. }\end{array}$ & $\begin{array}{l}\text { Formulation } \\
\text { containing } \\
\text { Lodhra as an } \\
\text { ingredient }\end{array}$ & $\begin{array}{l}\text { Indications } \\
\text { (Rogadhikar) }\end{array}$ & References \\
\hline 1 & $\begin{array}{l}\text { Rodhrasava } \\
\text { (lodhrasava) }\end{array}$ & $\begin{array}{l}\text { Kaphaj } \\
\text { Prameha }\end{array}$ & $\begin{array}{l}\text { G.N.Prameh } \\
\text { a/42-45; } \\
\text { A.H.Chi.12/ } \\
\text { 25-28. }\end{array}$ \\
\hline 2 & Vidangaristha & Prameha & $\begin{array}{l}\text { G.N.Asava.3 } \\
\text { 7-41; } \\
\text { B.R.37/19 ; } \\
\text { Sh.S.M.Kh.1 } \\
\text { 0/47-52. }\end{array}$ \\
\hline 3 & $\begin{array}{l}\text { Lodhradi } \\
\text { Kashaya }\end{array}$ & $\begin{array}{l}\text { Kaphaj } \\
\text { Prameha }\end{array}$ & $\begin{array}{l}\text { Vaidya } \\
\text { Chimtamani, } \\
\text { Prameha } \\
\text { prakaranam }\end{array}$ \\
\hline 4 & $\begin{array}{l}\text { Lodhradi } \\
\text { Kashaya }\end{array}$ & Madhumeha & $\begin{array}{l}\text { Basavrajiya } \\
\text { m } 9 / 59\end{array}$ \\
\hline 5 & $\begin{array}{l}\text { Haritkyadi } \\
\text { Kashaya }\end{array}$ & $\begin{array}{l}\text { Kaphaj } \\
\text { Prameha }\end{array}$ & $\begin{array}{l}\text { Ch. Chi. Ch. } \\
6 / 27 ; B . \quad R . \\
37 / 20-22\end{array}$ \\
\hline 6 & $\begin{array}{l}\text { Madhvasava } \\
\text { (Lodhrasava) }\end{array}$ & $\begin{array}{l}\text { KaphaPittaj } \\
\text { Prameha }\end{array}$ & $\begin{array}{l}\text { Ch. Chi. } \\
\text { 6/41-44 }\end{array}$ \\
\hline 7 & Usiradi kasaya & $\begin{array}{l}\text { Pittaj } \\
\text { Prameha }\end{array}$ & B. R. $37 / 24$ \\
\hline
\end{tabular}

(G.N.- Gada Nigraha, AH- Astang Hrdya, BRBhaisajya Ratnawali, Sh. S.- Sharangdhar Samhita, Ch. Chi-Charak Chikitsa sthan)

\section{Lodhra for Diabetes}

Diabetes is a chronic, metabolic disease characterized by elevated levels of blood glucose (or blood sugar), which leads over time to serious damage to the heart, blood vessels, eyes, kidneys, and nerves (18). Hexane extract of S. cochinchinensis leaves has potential of antidiabetic property to treat type 2 diabetes. The methanolic extract of stem bark shows significant decrease in plasma insulin and liver glycogen levels in treated diabetic rats. The glycemic response recorded in Symplocos cochinchinensis hexane extract treated group indicated that the extract had the potential to improve insulin sensitivity. The Symplocos species aggravates the degree of impairment slightly but significantly, indicating the potential function in reducing insulin resistance (19). The ethanolic extract of leaves showed hypoglycemic activity in rats and anticancer activity against Friend virus- leukaemia (solid) in mice. The extract of the leaves and of stems showed activity against human epidermoid carcinoma of the nasopharynx in tissueculture (8). Symplocos cochinchinensis groups showed 
significant hypoglycemic activity along with improved insulin sensitivity possibly by improving one or more defects viz. insulin receptor, insulin receptor substrate, glucose transporters or enzymes involved in phosphorylation of glucose (20,21). Secretion and/or insulin action or could be related to the interference on absorption of dietary carbohydrates as well as disaccharides in small intestine leading to the suppression of meal induced increase of plasma glucose thus showing hypoglycemic activity (22).

\section{Management of Diabetic Complication}

Diabetes complications are divided into microvascular (due to damage to small blood vessels) and macrovascular (due to damage to larger blood vessels). Microvascular complications include damage to eyes (retinopathy) leading to blindness, to kidneys (nephropathy) leading to renal failure and to nerves (neuropathy) leading to impotence and diabetic foot disorders (which include severe infections leading to amputation). Macrovascular complications include cardiovascular diseases such as heart attacks, strokes and insufficiency in blood flow to legs. There is evidence from large randomized-controlled trials that good metabolic control in both type 1 and 2 diabetes can delay the onset and progression of these complications. Good metabolic control can delay the onset and progression of diabetic retinopathy. control of high blood glucose, control of high blood pressure, intervention with medication in the early stage of kidney damage, and restriction of dietary protein. (23)

The clinical course and prognosis of health and life of diabetic patient are now determined by so called complications of diabetes. The characteristic progressive damage to the eyes, kidney, and nerves and heightened susceptibility to heart disease, gangrene and stroke are most prominent in metabolic disorders. These complications are Diabetic microangiopathy (Progressive change in capillaries leads too renal and retinal disease), Arterial disease, local tissue damage (reason behind Neuropathy and cataract), Diabetic neuropathy (Malfunctioning of cardiovascular system, respiratory system, urinary and sexual function) and infection (Tuberculosis, Fungal infection to skin \& UTI or anaerobic infection of deep tissues). These complications can be managed by improvement of metabolic control, prevention of vascular disease, prevention of infections and preservation of organ function) (24).

Significant decrease in plasma and liver TC (total Cholesterol), TG (triglyceride) and lipids recorded in Lodhra groups indicates the role of Symplocos in preventing dyslipidemia and lipotoxicity. Synthetic antidiabetic drugs commercially available in the market are often not able to tackle dyslipidemia, thus raising the risk of cardiovascular complications. Hence, these results can be considered significant against diabetic dyslipidemia. These results are also in accordance with previously reported lipid lowering property in high fat diet-low STZ induced hyperglycemic rats (25).
Antibacterial Activity- Antibacterial property helps the diabetic patient to fight against infections caused over skin, urinary tract etc. Its antibacterial property is helpful in prevention of complications. Ethanolic extract of $S$. racemosa Roxb shows good antibacterial activity as compared to petroleum ether, but it has poor antibacterial activity against gram negative microorganism like $P$. aeruginosa and E. Coli (26). Methanolic extracts of leaves, root and stem barks of $S$. cochinchinensis and their fractions obtained by partition (petrol, dichloromethane and ethyl acetate) were screened for antimicrobial activity. All crude extracts and fractions showed a broad spectrum of antibacterial activity that was enhanced on fractionation (27).).

Anthelmintic effect: Anthelminthic property of the Lodhra was helpful to prevent metabolic disorder caused due to helminths. The anthelmintic activity of petroleum ether, chloroform and ethanol extract of bark $S$. racemosa on adult Indian earthworms. This reveals that the Ethanolic extract had more anthelmintic property as compared to other extract (28).

Anti-inflammatory activity: Major complications in diabetes mellitus are the reason behind inflammation in body tissues, organs etc. so the anti-inflammatory property may be utilized against complications. It may be used as preventive measure against diabetic complications and for the patients relieves. Methanol extract of leaves have effective in-vitro antiinflammatory activity. The extract also showed significant in-vivo anti-inflammatory activity (53\%) at the dose of $400 \mathrm{mg} / \mathrm{ml}$ (29).

Anti-oxidant activity: Antioxidant property are helping in person to avoid many ailments and keep body tissues healthy. It scavenges the harmful free radicles that are either accumulated in the body or produces during abnormalities in metabolism. Thus it help in protection of vital cell against metabolic disorder and complications of diabetes. The methanol extract of Lodhra leaves showed very good scavenging activity on 2,2-diphenyl- picrylhydrazyl (DPPH), hydroxyl, nitric oxide radicals, as well as high reducing power. The extract also showed strong suppressive effect on lipid per-oxidation (30).

Anti-ulcer property: Antiulcer property of Lodhra may be utilized against tissue damage in gastrointestinal tract and it may play a preventive role when used in antidiabetic formulations. The aqueous and ethanolic extracts of $S$. racemosa showed anti-ulcer property. Anti-secretory activity (decrease in gastric volume) and reduction in free and total acidity of the extracts at $500 \mathrm{mg} / \mathrm{kg}$ was noticed in pylorus ligation induced ulcer model (31).

Hypolipidemic activity: Hypolipidemic activities of ethanolic extracts of $S$. racemosa (ESSR) were studied by triton-WR1339 (acute) and high fat diet induced (chronic) hyperlipidemic rat models. ESSR treatment 
prevented the increased formation of malondialdehyde (MDA) in liver and restored the depleted liver antioxidants, glutathione, superoxide dismutase, catalase significantly. It also restores TC, TG, VLDL, HDL and LDL level. The hypolipidemic activity of ESSR may be due to presence of flavonoids phenolic compounds, phenolic glycosides and steroids (32). Methanolic extract of bark showed antilipidemic activity as evidenced by significant decrease in serum TC, TG, LDL-C levels and significant increase in HDL$\mathrm{C}$ level in treated diabetic rats. It also restored the altered plasma enzymes (SGOT, SGPT and ALP), total protein, urea and creatinine levels to near normal (33).

Neuro-supportive role: Lodhra extract are having nervine tonic and good healing properties that may be utilized in diabetic wound healing as well as nervine damage. It may play a preventive role over neuropathy complications as well as body tissue damage complications. Locoracemosides A, B and C from nbutanol soluble extract from bark of $S$. racemosa showing in vitro inhibitory activity against $\alpha$ chymotrypsin (34).

Hepato-protective activity: High blood sugar are reported for damaging the liver tissue and altering the metabolic equilibrium. Liver is key player for metabolism in the body so protection of hepatic tissue may impart to fight against diabetic complications. Ethanolic extract of bark of $S$. racemosa showed significant dose-dependent restoration of serum enzymes, bilirubin, albumin, total proteins and antioxidant levels against carbon tetrachloride induced hepatic damage in rats. Notable improvements were observed morphologically and histopathologically (35).

Lipoxygenase and urease inhibitory activity: These enzymes promote the development of kidney stones, polynephritis, peptic ulcer disease etc. so inhibition of this enzyme helps in proper metabolism and prevent from additional problems due to complications. Phytoconstituent, 1-ethyl brachiose- 3 '-acetate and triacontyl palmitate displayed the inhibitory potential against lipoxygenase and urease enzyme (36). Triacontanyl palmitate isolated from n-hexane soluble fraction of bark of $S$. racemosa inhibit the urease enzymes in a concentration-dependent manner (37).

\section{Conclusion}

Diabetes is grasping the human population in accelerated manner due to disturbance in lifestyle, mind status and genome. The complications arise due to diabetes or during diabetic condition was more concerning prospective in treatment approach now days. Lodhra was used in antidiabetic formulations in Ayurveda for the management of Prameha (Diabetes). In $21^{\text {st }}$ century when the research involves the language of modern science, provide data based evidence about antidiabetic property of Lodhra. Other pharmacodynamics of Lodhra can be utilized against diabetic complications and it play major role in overall management of diabetic patients when used in formulation. Alongside it also proof that ancient wisdom was already utilizing these properties for the management of Prameha.

\section{Acknowledgement}

Author is very much thankful to the DST, Ministry of Science and Technology, Govt. of India for DST- INSPIRE fellowship and financial support for study.

Author is also thankful to Dr. Pooja Singh, JR-II, Department of Rasa Shastra, Faculty of Ayurveda, Institute of Medical Sciences, Banaras Hindu University, Varanasi for their support in literature survey.

\section{References}

1. Patwardhan B,Warude N, Pushpangadan P, Bhatt N. Ayurveda and traditional chinese medicine: A comparative overview. Evid. Based Complement Alternate Med. 2005;2(4); 465-73

2. Bora K.S. and A. Sharma. The genus Artemisia: A comprehensive review. Pharm. Bio. 2011;49;10109.

3. De Silva L.B., U.L.L. De Silva and M. Mahendran. The chemical constituents of Symplocos racemosa Roxb. J. Natl. Sci. Council Sri Lanka. 1979;7;1-3.

4. Watt, G. Dictionary of the Economic Products of India. periodical expert book agency, New Delhi, India. 1972.

5. Kumar DC. Pharmacognosy can help minimize accidental misuse of herbal medicine.curr. science. $2007 ; 93(10): 1356-1358$.

6. WHO,Traditional Herbal Remedies for Primary Health Care. Access on 10/10/2015; Available from: http://apps.searo.who.int/PDS_DOCS/B4572.pdf.

7. ICMR-WHO workshop outcome, Guideline for Management of Type 2 Diabetes, ICMR New Delhi. 2005 ; sec-1;p 1.

8. C.P. Khare. Indian Medicinal Plants An Illustrated Dictionary. Springer Science+BusinessMedia, New York, USA. 2007; 635-36.

9. Nagore D.H., Kuber V.V., Patil P.S. and Deshmukh T.A.. Assessment of loturine from different extracts of bark of Symplocos racemosa (Roxb.) by using high performance thin layer chromatography. Int. J. Anal. Bioanal. Chem. 2012;2;204-8.

10. Badoni R, Semwal DK, Kothiyal SK and Rawat U. Chemical constituents and biological applications of the genus Symplocos . J. Asian Nat. Prod. Res. $2010 ; 12 ; 1069-80$.

11. Ishida J, Wang HK, Masayoshi O, Cosentino CL, Hu CQ and Lee KH. Anti-HIV activity of Harman, an anti- HIV principle from symplocos cocchinchinensis and its derivatives. J. Nat. Prod. 2001; 64; 958-60.

12. Ahmad VU, Abbasi MA, Hussain H, Akhtar MA, Farooq U, Fatima N etal. Phenolic glycosides from Symplocos racemosa: Natural inhibitors of phosphodiesterase. Phytochemistry . 2003;63;21720.

13. Ahmad VU, Zubair M, Abbasi MA etal. Phenolic glycosides from Symplocos racemosa. Z. Naturforschung B. 2005; 60;1101-1104. 
14. Ahmad VU, Rashid MA, Abbasi MA, Rasool N and Zubair M. New salirepin derivatives from Symplocos racemosa. J. Asian Nat. Prod. Res. $2007 ; 9 ; 209-15$.

15. Abbasi, M.A., V.U. Ahmad, M. Zubair, S.A. Nawaz, M.A. Lodhi, U.Farooq and M.I. Choudhary, 2005. Lipoxygenase inhibiting ethyl substituted glycoside from Symplocos racemosa. Nat. Prod. Res., 19:509-515.

16. ALI M, Bhutan KK and Srivastava TN. Triperpenoid from symplocos racemose bark. Phytochemistry 1990;29(11); 3601-04.

17. Sharma PV. Dravyaguna Vijanana part-2. Varanasi; Choukhambha Bharati Academy; 2006. 616p.

18. WHO, About Diabetes. Access on 1/11/2015; Available from : htmlhttp://www.who.int/diabetes/ en/.

19. Sunil C, Ignacimuthu S, Agastian P. Antidiabetic effect of Symplocos cochinchinensis (Lour.) S. Moore. in type 2 diabetic rats. Journal of Ethnopharmacology. 2011;134; 298-304.

20. Benwahhoud M., Jouad H, Eddouks M, Lyoussi B. Hypoglycemic effect of Suaeda fruticosa in streptozotocin-induced diabetic rats. Journal of Ethnopharmacology. 2001; 76; 35-38.

21. Hilaly J E, Lyoussi B. Hypoglycemic effect of the lyophilized aqueous extract of Ajuga iva in normal and streptozotocin diabetic rats. Journal of Ethnopharmacology. 2002; 80; 109-13.

22. Ortiz-Andrade RR, Garcia-Jimenez S, CastilloEspana P, Ramirez-Avila G, Villalobos-Molina R, Estrada-Soto S. Glucosidase inhibitory activity of the methanolic extract from Tournefortia hartwegiana: an anti-hyperglycemic agent. Journal of Ethnopharmacology. 2007; 109; 48-53.

23. WHO, About diabetes, access on 2/11/2015. Available from : http://www.who.int/diabetes/ action_online/basics/en/index3.

24. WHO expert committee on Diabetes mellitus. WHO technical report series 646. second report 1980; 35$38 \mathrm{p}$.

25. Xing X, Zhang Z, Hu X, Wu R, Xu C. Antidiabetic effects of Artemisia sphaerocephala Krasch Gum, a novel food additive in China, on streptozotocininduced type 2 diabetic rats. Journal of Ethnopharmacology. 2009; 125; 410- 16.

26. Devmurari VP. Antibacterial Evaluation and Phytochemical Screening of Symplocos racemosa Roxb. International Journal of PharmTech Research. 2010; 2(2);1359-63.
27. Khan MR, Kihara M, Omoloso AD. Antimicrobial activity of Symplocos cochinensis. Fitoterapia. $2001 ; 72 ; 825-28$.

28. Sunil C, Agastian P, Kumarappan C, Ignacimuthu S. In vitro antioxidant, antidiabetic and antilipidemic activities of Symplocos cochinchinensis (Lour.) S. Moore bark. Food and chemical toxicology. 2012; $50 ; 1547-53$.

29. Narsimharao RL, Bhavy B, Pavani K, Swapna A, Prasoona CH. Anthelminthic activity of Symplocos racemosa. International Journal of Pharmacy and Biological Sciences.2011; 1(3); 198-230.

30. Vadivu R and Lakshmi KS. In vitro and in vivo anti -inflammatory activity of leaves of Symplocos cochinchinensis(Lour) Moore ssp laurina. Journal of Bangladesh Pharmacological Society. 2008; 3;1214.

31. Sunil C, Ignacimuthu S. In vitro and in vivo antioxidant activity of symplocos cochinchinensis S. moore leaves containing phenolic compounds. Food and chemical toxicology. 2011;49;1604-09.

32. Krishna CG, Divya M, Rohita K, Dolly S and Kumar KP. Pharmacological evaluation of symplocos racemosa barks extracts on experimentally induced ulceritis in rat model. Elixir International Journal. 2013;55 ; 12964-66.

33. Durkar AM, Patil RR, Naik SR. Hypolipidemic and antioxidant activity of ethanolic extract of symplocos racemosa Roxb. In hyperlipidemic rats. Indian Journal of Experimental Biology. 2014;52; 36-45.

34. Rashid MA, Ali Z, Abbasi MA, Rasool $\mathrm{N}$ and Zubair $M$ et. al. Chymotrypsin inhibiting benzyl derivatives from symplocos racemosa. Planta Med. 2008; 74; 111-15.

35. Wakchaure D, Jain D, Singhai AK and Somani R. Hepatoprotective activity of symplocos racemosa bark on carbon tetrachloride-induced hepatic damage in rats. J. Ayurveda Intregative Med. 2010; 2; 137-43.

36. Abbasi MA, Ahmad VU, Subair M, Nawaz SA, Lodhi MA, Farooq U, and Choudhary MI. Lipoxygenase inhibiting ethyl substituted glycoside from symlpocos racemosa. Nat. Prod. Res. 2005;19; 509-15.

37. Lodhi MA, Abbasi MA, Choudhary MI and Ahmad VU. Kinetics studies on triacontanyl palmitate: A urease inhibitor. Nat. Prod. Res. 2007; 21;721-725. 